Marine Policy

July 2020, Volume 117, Pages 103045 (10p.)

http://dx.doi.org/10.1016/j.marpol.2018.01.028

http://archimer.ifremer.fr/doc/00423/53474/

(C) 2018 Published by Elsevier Ltd

Archimer

http://archimer.ifremer.fr

\title{
Findings from an exploratory study on the governance of a French fishery
}

\author{
Tissière Laurie ${ }^{1,2,{ }^{*}}$, Mahévas Stephanie ${ }^{2}$, Trouillet Brice ${ }^{1}$
}

\author{
1 Université de Nantes, CNRS, UMR LETG, Chemin de la Censive du Tertre, BP 81227, 44312 Nantes \\ Cedex 3, France \\ 2 Unité Ecology and models for fisheries, IFREMER, rue de l'île d'Yeu BP 21105, 44311 Nantes Cedex \\ 03, France
}

* Corresponding author : Laurie Tissière, email address : laurie.tissiere@univ-nantes.fr

\begin{abstract}
:
In marine fisheries science, the application of social sciences and the increasing use of a multidisciplinary approach have enriched fisheries research through new paradigms. The stance on fisheries governance aims to complement bio-economic approaches and to break with the "tragedy of the commons" premise by focusing on the institutions and network actors at the heart of knowledge, representations, actions and decisions systems. Although the French-European context is largely determined by The Common Fisheries Policy, governance levers and an organised network of actors have been identified in demersal and benthic fisheries. In the present study, the observation of dialogue meetings identified the stakeholder strategies and interactions used to activate these levers, while the narrative of the process provided insight into methodological (relevance of the chosen method) and practical (efficiency of the governance) limitations, and outlooks.
\end{abstract}

Keywords : Governance, Fishery, Common Fisheries Policy, Stakeholders, Social interactions 


\section{Introduction}

"Each man is locked into a system that compels him to increase his herd without limit - in a world that is limited [...] Freedom in a commons brings ruin to all" [1]. These words could not be more relevant to the current global environmental crisis, as they predict the probable shift from scientific research conducted to create economic wealth towards the type of knowledge valuable for preserving ecosystems [2]. The "tragedy of the commons" is a theory that is often used in fisheries science and management. Conventional economics maintains that competition between professional fishers will inevitably lead to an "every man for himself" attitude, and the undivided and subtractive character of the resource they exploit to a "race for fish" [3-8]. In his critique of the common resource, written in the decisive context of the Cold War, Hardin compared two opposing solutions: administration and privatisation. In other words, he posited that the only way to prevent resource overexploitation is through government leadership or private appropriation [9, 10]. Once more, this was addressed in fisheries management through public administrative or market-based conservation and access control measures [11]. This State-business "dichotomy" has been widely contested and the "Hardinian" theory refuted, first by Ostrom [12-14] and then by fisheries specialists [15-20] who, through empirical feedback, highlighted a third regulation pathway: governance, or the ability of communities to look after themselves and to take the collective steps required for an equitable and sustainable use of common resources, with varying degrees of success [21].

There is no generally-accepted and fixed definition of governance [22]; it is a term with several meanings that can be used in both the private and public sphere, by international institutions (e.g. Organisation of Economic Co-operation and Development, International Monetary Fund) to promote liberalism, by Non-Governmental Organisations (NGOs) to reinforce them lobbying efficiency and by local stakeholders to enhance democracy [23]. In all cases, governance is a notion that re-examines the role of central government for new levels and actors [24]. Governance can include traditional government, but it primarily refers to the integration of other institutions and scales that have a capacity for action $[25,26]$. In the context of marine fisheries, the notion of governance leans towards the involvement of fishers and other stakeholders - mainly actors for the marine environment preservation - in management $[18,19,27]$. The opening up of this disciplinary field, especially to the social sciences for analysis of actors' interactions, is a direct consequence of this paradigm shift in environmental governance in general, and fisheries governance in particular. However, it is mainly so-called developing countries and traditional societies, that is to say places where administration and industrialisation levels - of fisheries for instance - are considered as low, that provide the setting for these types of studies [28]. In the European context and $a$ fortiori the French one, where administration and industrialisation levels are considered as high, it should not be possible to think fisheries in terms of governance [29]. Three hypotheses may be put forward: (i) the Common Fisheries Policy (CFP) does not recognize governance as a regulation pathway, (ii) the network of actors is not sufficiently structured and (iii) this network is not suitable for collective action.

In order to test these hypotheses, a two-stage study was conducted on the benthic fishery of the Bay of Biscay. Part one of the article summarised the literature review to describe the case study, in particular with respect to the first two hypotheses. In other words, the consultation of legal and working documentation has permitted to identify the division of competences between governmental and non-governmental institutions. Then, a direct and a nonparticipatory observation of cooperation scenes, aiming to produce collective action on the 
case study, have been developed. It rested on discussion and organisation mechanisms. Part two is the reconstruction of the observation method and results and of the discussion to compare these with the third hypothesis. Finally, the research method and the European fisheries policy are discussed from a governance perspective.

\section{Condition and challenges of fisheries}

This first part will summarise benthic and demersal fisheries in the Bay of Biscay in terms of biological and socio-economic challenges, particularly the functioning of their management.

\subsection{The fishery as a system}

A fishery is an ensemble consisting of a fleet, a species, a zone and a fishing season and when several fleets and species make a coherent entity, this entity is known as a mixed fishery [30, 31]. Fisheries are therefore systems in which other parameters (e.g. terrestrial, institutional) come into play, thus referring to other conceptual tools, such as complex systems [32, 33], social-ecological systems [34] or fishery geosystems [35]. Here, the term "fishery" is taken in its broadest sense and with the two-tier definition that was formulated by Kooiman [19, 36] and then re-used by Jentoft [37-39]: namely the "system-to-be-governed" and the "governing system". The first tier focuses on the meeting of one or several groups of fishers with one or several fish populations, and takes a more general view of the sea and its users. The second tier helps to describe the web of actors and institutions (in)directly involved in the management of the first tier.

\subsection{The "system-to-be-governed"}

The Bay of Biscay is an area of the North-East Atlantic, bounded in the north by Pointe de Penmarc'h (France) and in the south by Cape Ortegal (Spain). Its waters contain abundant fish, mainly above the continental shelf, and for this reason, the study only includes the Exclusive Economic Zone claimed by France [40]. Coastal fisheries in the Bay of Biscay appear to be fundamentally based on at least three benthic or demersal species: Norway lobster (Nephrops norvegicus), European hake (Merluccius merluccius) and Common sole (Solea solea). They account for nearly one third of the turnover of French Atlantic coast auctions [41]. According to the SACROIS database, more than 600 vessels from different métiers - that is to say an aggregation of vessels targeting the same species, using the same gears in given area and season [42] - depend on them. However, there are some disparities in catches and landings at both spatial and temporal levels. Some regional and seasonal patterns of fishing effort can be explained by biological cycles and species distribution. The Norway lobster is a sedentary species of the Grande Vasière [43, 44], an area that is also a habitat for juvenile hake which, once adult, migrate in winter and spring towards the continental slope for spawning [45-47]. Juvenile sole live in coastal shelterbelts and estuaries, with mature individuals reproducing in the deeper zones of the continental shelf during winter [48, 49]. This information is summarised in Fig. 1, but it is important to bear in mind that the map is only a static representation of spatial and temporal dynamics (e.g. flow of ships between home ports, fishing zones and landing sites; sole and hake migrations; fishing seasons). 


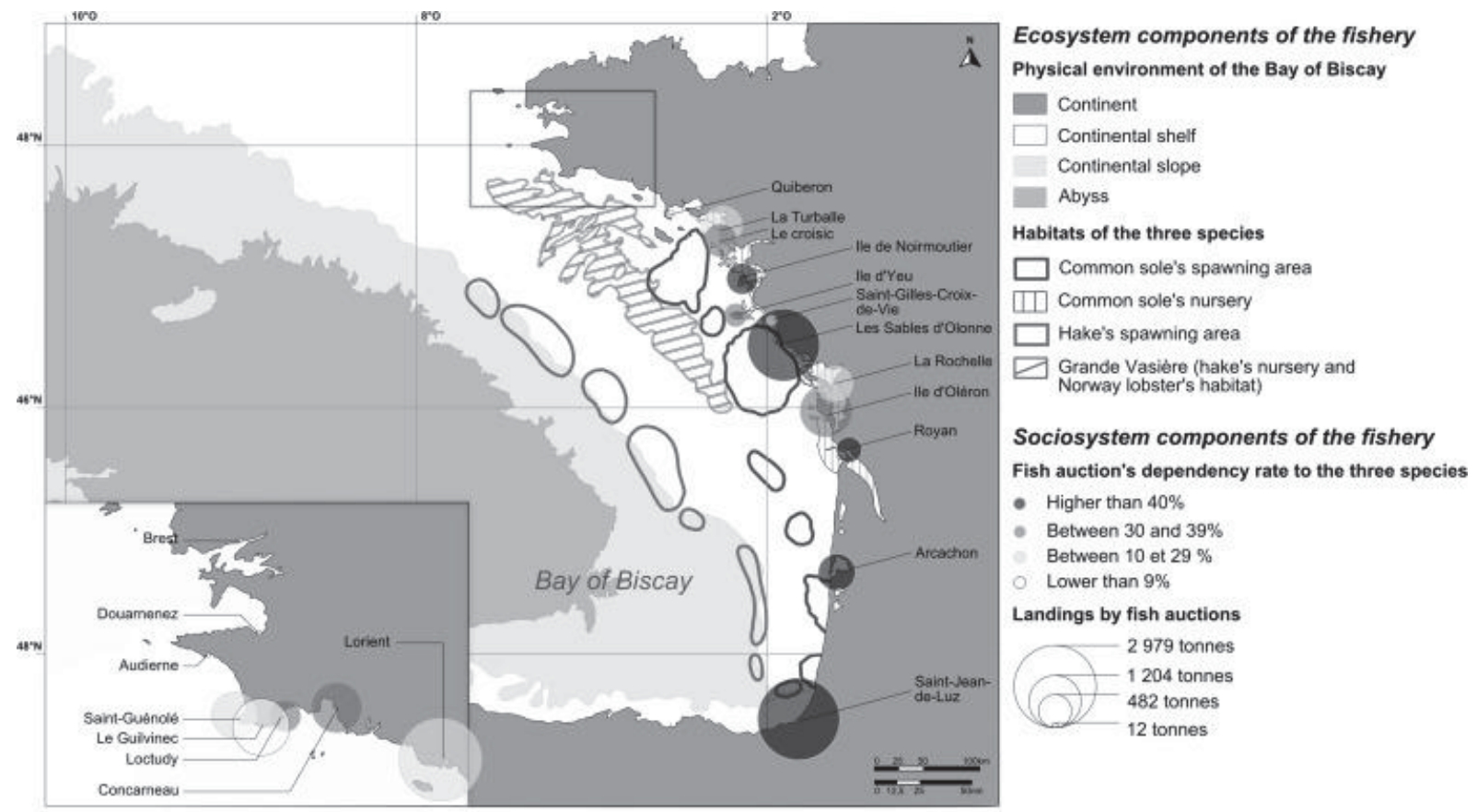

Fig. 1: Map of the system-to-be-governed

One of the challenges of fisheries policy is to take into account the biological and socioeconomic components [50]. Fig. 2 shows the biomass evolution of reproductive adults of the three aforementioned species and fisheries landings. The separation between these two curves, i.e., a satisfactory balance between exploitation and conservation, is the primary objective of management. ICES stocks, catches and landings assessments have shown that on an ad hoc or more permanent basis, resources have been exploited above their biological limits; findings that justify the deployment of a full range of regulatory measures for the activity [51].

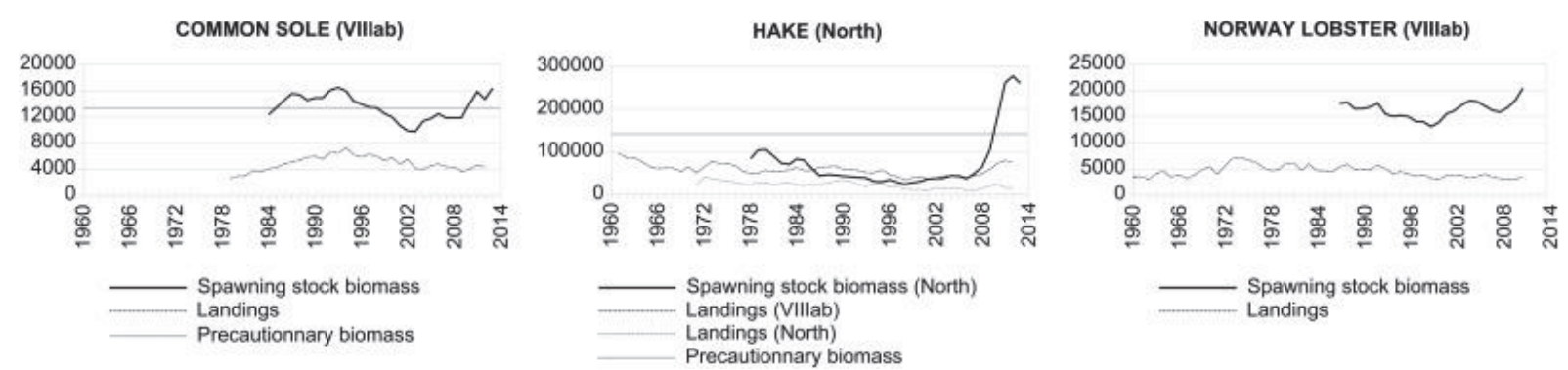

Fig. 2: Status of three species of the benthic and demersal fishery of the Bay of Biscay (Source - ICES)

Familiarity with the system underpins the entire fisheries management process. Although ICES expertise influence decision-making, it is include in a complex institutional framework which should be described.

\subsection{The "governing system"}

- The role of government

France has a tradition of centralisation, but in the 1980s it pursued a decentralisation policy by creating fully-functioning local authorities with powers that covered, for example, economic development, environmental protection and port planning [52]. At the same time, the European Community affirmed its position and officially created the CFP, the objectives of 
which are particularly guided by international texts such as the United Nations Convention on the Law of the Sea (UNCLOS, 1982), the Convention on Biological Diversity (CBD, 1992) or the Code of Conduct for Responsible Fisheries (CCRF, 1995) [53]. These texts address issues such as food sovereignty or the sustainable productivity of fisheries [54]. The CFP plays a crucial role, but three other scales (infra-national national and international) are directly or indirectly involved in marine fisheries management.

Fisheries management in Europe and France is frequently criticised for both its environmental and socio-economic expectations [55-61]. Some claim the CFP reorganisations that impact fishing communities go against the principles of social justice, whereas others call for a higher priority to be given to the conservation of marine ecosystems. This means that stakeholder involvement needs to be called into question to integrate all issues that lead to the creation of "governance levers".

- Governance levers

Fisheries policy comes under the responsibility of the European Union, in which the participatory governance described by Gray [18] and Pomeroy's decentralisation [17] do not exist today in an explicit form. However, the levers of stakeholder involvement in the management of the Bay of Biscay fishery have on the one hand been created by French and European regulations (as indicated in Table 1), and on the other have emerged from the organisation of local actors.

Table 1. Evolution of the fisheries institutional rules in Common Fisheries Policy (Source Official Journal of the European Union; Legifrance)

\begin{tabular}{|c|c|c|c|}
\hline Year & European rule & French rule & Creation or reform \\
\hline 1970 & $\begin{array}{l}\text { Council Regulation on the Common } \\
\text { Organisation of the Market in Fishery } \\
\text { Product }\end{array}$ & - & Producer Organizations \\
\hline 1976 & $\begin{array}{l}\text { Council Regulation on the recognition of } \\
\text { producers' organizations in the fishing } \\
\text { industry }\end{array}$ & - & Producer Organizations \\
\hline 1983 & $\begin{array}{l}\text { Council Regulation establishing a } \\
\text { Community system for the conservation } \\
\text { and management of fishery resources }\end{array}$ & - & Common Fisheries Policy \\
\hline 1991 & - & $\begin{array}{l}\text { Organisation of fisheries and aquaculture } \\
\text { inter-professional organisation law }\end{array}$ & Fisheries Committees \\
\hline 1992 & $\begin{array}{l}\text { Council Regulation establishing a } \\
\text { Community system for fisheries and } \\
\text { aquaculture }\end{array}$ & - & Common Fisheries Policy \\
\hline 1999 & $\begin{array}{l}\text { Resolution on the regionalisation of the } \\
\text { Common Fisheries Policy }\end{array}$ & - & - \\
\hline 2000 & $\begin{array}{l}\text { Council Regulation on closer dialogue } \\
\text { with the fishing sector and groups } \\
\text { affected by the common fisheries policy }\end{array}$ & - & $\begin{array}{l}\text { European trade organisations, Advisory } \\
\text { Committee on Fisheries and Aquaculture }\end{array}$ \\
\hline 2002 & $\begin{array}{l}\text { Council Regulation on the conservation } \\
\text { and sustainable exploitation of fisheries } \\
\text { resources under the Common Fisheries } \\
\text { Policy }\end{array}$ & - & Common Fisheries Policy \\
\hline
\end{tabular}




\begin{tabular}{|c|c|c|c|}
\hline 2004 & $\begin{array}{l}\text { Council decision establishing Regional } \\
\text { Advisory Councils under the Common } \\
\text { Fisheries Policy }\end{array}$ & - & Regional Advisory Councils \\
\hline 2009 & - & Grenelle of the Sea's Blue Book & $\begin{array}{l}\text { Concerted exploitation and management } \\
\text { units }\end{array}$ \\
\hline 2010 & - & $\begin{array}{l}\text { Agriculture and fisheries modernisation } \\
\text { law }\end{array}$ & Fisheries Committees, maritime councils \\
\hline 2012 & $\begin{array}{l}\text { Regulation of the European Parliament } \\
\text { and of the Council amending Council } \\
\text { Regulation on the conservation and } \\
\text { sustainable exploitation of fisheries } \\
\text { resources under the common fisheries } \\
\text { policy }\end{array}$ & - & Common Fisheries Policy \\
\hline 2013 & $\begin{array}{l}\text { Regulation of the European Parliament } \\
\text { and of the Council on the Common } \\
\text { Fisheries Policy, amending Council } \\
\text { Regulations on the conservation and } \\
\text { sustainable exploitation of fisheries } \\
\text { resources under the Common Fisheries } \\
\text { Policy and repealing Council Decision } \\
\text { establishing Regional Advisory Councils } \\
\text { under the Common Fisheries Policy }\end{array}$ & - & Advisory Councils \\
\hline
\end{tabular}

First, there are the institutions that represent fishers, such as the fisheries committees recognised by France, the Producer Organizations (POs), recognised by Europe, and the trade unions. Their role is to represent the interests of fishers in government and to define some aspects of the activity (e.g. allocation of quotas and licences, fishing plans) [62-65]. Two such institutions have more or less recently modified the traditional decision-making processes of maritime affairs in Europe and in France: the Advisory Councils (ACs) and maritime councils (CMFs). The ACs act as a link between the industry, decision-makers and NGOs during, for example, the development of management plans [66-69]. Unlike ACs, the CMFs are ad hoc meetings of French maritime actors in the implementation of Integrated Coastal Zone Management (ICZM) and Maritime Spatial Planning (MSP). Fisheries are just one of the topics addressed and the CMFs are still managed by the government [70]. Finally, more informal meetings with non-hierarchical users, political authorities, scientists and NGOs are social innovations that provide the opportunity to respond collectively to a fisheries management or land-use planning issue. They do not produce regulations but set, at the very least, common goals for addressing situational and structural issues [71-74].

Regulations therefore tend to make regional management and make actors accountable. The institutional structure is productive but the power relations between the actors maintain a downward trend (Fig. 3) and a nested skills approach still remains complex as there are few opportunities for non-governmental actors to take any action beyond 12 nautical miles from the baseline (Figure 4). 


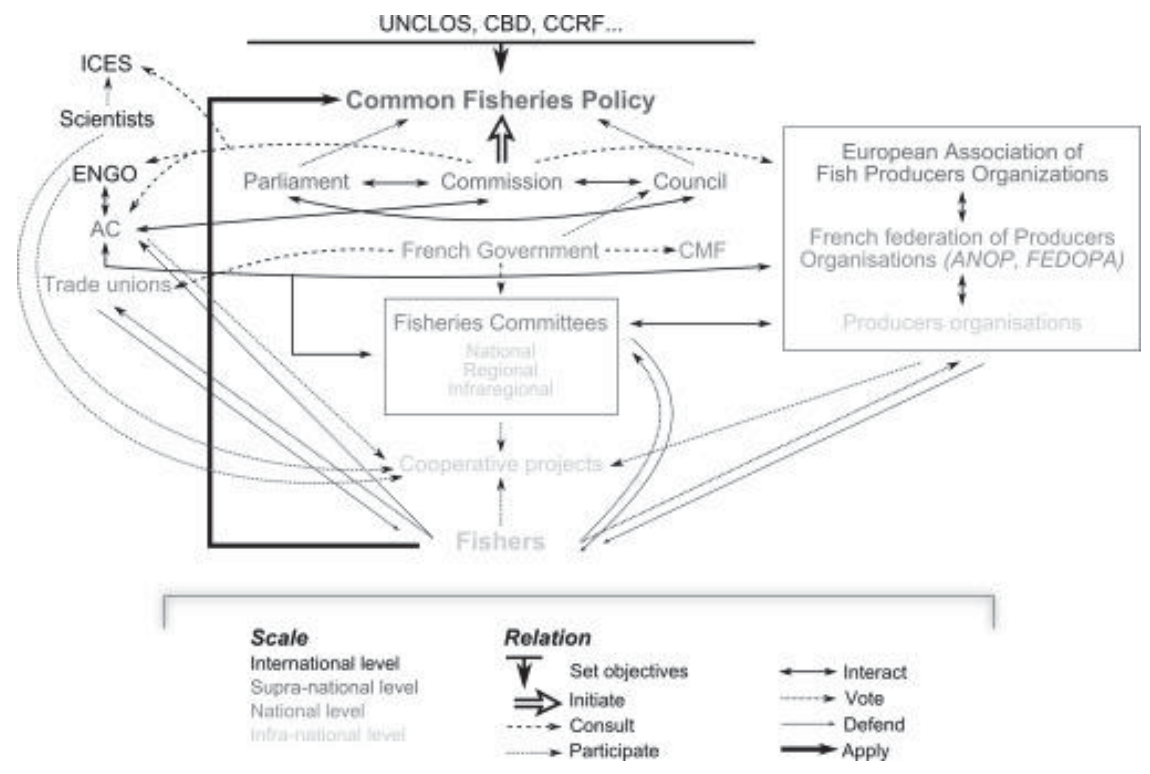

Fig. 3: Institutional framework and relationship

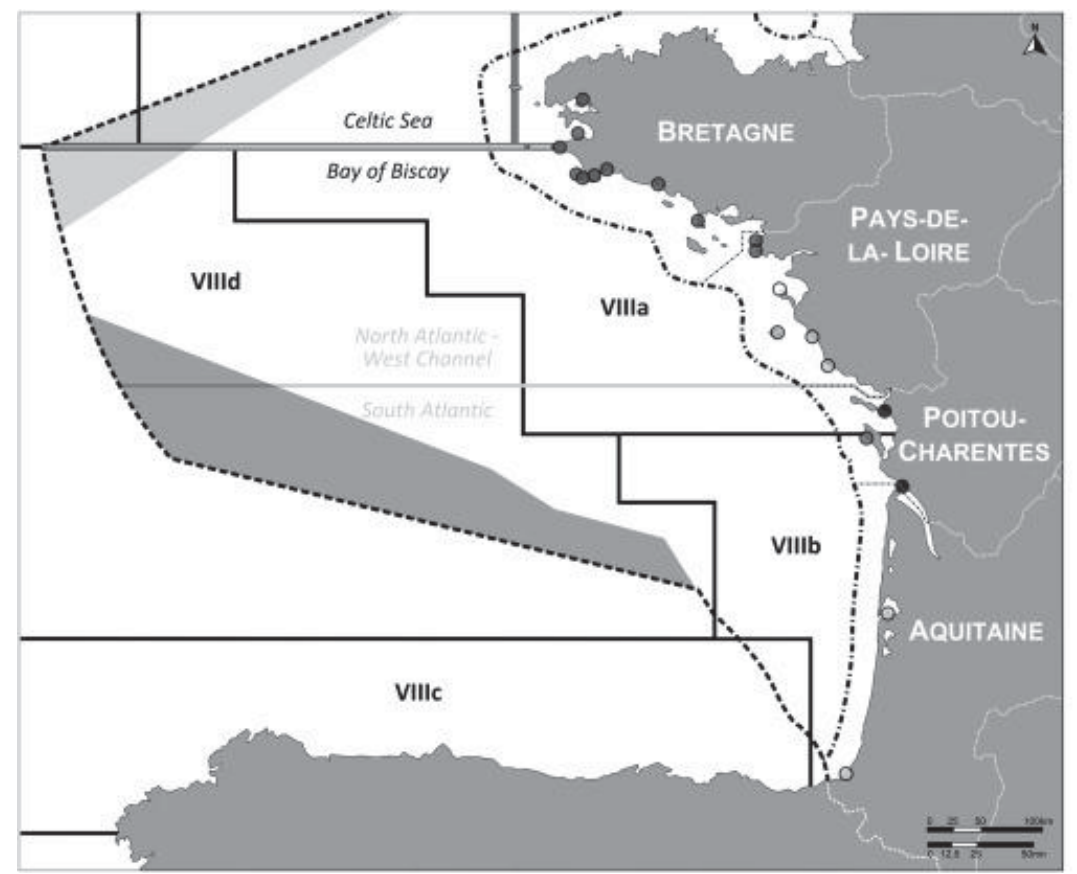

Main producer organizations in the fish port

- Pécheurs de Bretagne

- OPPAN

- OP Vendée

- FROM Sud-Ouest

OP La Cotinière

- Pécheurs d'Aquitaine

Marine and continental boundaries

National boundary

- Regional boundary

..... EEZ claimed by France

EEZ claimed by Spain

EEZ claimed by United Kingdom

..... French territorial sea

Other delimitations

- ICES Division

- Regional Sea (MSFD)

$=$ RAC limit

CMF limit

Fig. 4: Map of the governing system

\section{Presentation of the outcomes}

Many studies have been conducted on decision-making powers in fisheries in Europe [53, 75]. Documentary research on the Bay of Biscay benthic fishery has reiterated the CFP's centralised mode of operation and also enabled it to be weighted by identifying the governance levers - tenuously recognised by the public authorities - that structure the stakeholder network. What is needed now is a more in-depth understanding of these governance levers as regards the actors involved, objects and issues, terms and conditions between actors, etc. 


\subsection{The choice of method}

In the one hand hand, the Chicago School has largely study social interactions as an psychological and sociological - indicator to understand social facts [e.g. 76, 77]. In the other hand, "social capital" is a holistic concept introduced by Bourdieu and Coleman that sets out the effect of social networks on individual behaviour [78, 79]. Social interactions and capital have been re-used in natural resource management contexts to qualify the social constructs and common rules that result in self-regulated exploitation [28, 80-84]. Such approaches elaborate a theory about the social causal chain "interaction-capital-management" applied to the environment. The present exploratory survey aims to illustrate it. The method chosen to understand it is direct and non-participant observation of dialogue meetings. Dialogue here is understood in the broadest sense the French term concertation as per Mermet that is, as collaborative problem solving [85].

\subsection{Observation stages}

- Observation frameworks: presentation of the meetings and actors

Dialogue meetings are considered as the concrete expression of governance levers because they are supported by specific institutions or multi-stakeholder project. First, all meetings dealing about benthic fisheries of the Bay of Biscay have been identified thanks to formal or informal discussion. Then, because these meetings are not open to the public, the organiser has been solicited for an individual interview while the permission to observe the next meeting was asked. Thus, three meetings have been observed. They can only be used as examples because they are limited in number and therefore not representative. The objectives, participants and context of the meetings are detailed in Table 2.

Table 2: Presentation of the observed meetings

\begin{tabular}{|l|l|l|l|l|}
\hline Name of the meeting & Short name & $\begin{array}{l}\text { Object and initial } \\
\text { objectives }\end{array}$ & Place & Number of participants \\
\hline $\begin{array}{l}\text { The first regional meeting } \\
\text { of stakeholders of a } \\
\text { European research project } \\
\text { on the effect of bottom } \\
\text { trawling in the Grande } \\
\text { Vasière }\end{array}$ & Meeting 1 & $\begin{array}{l}\text { Agree on a set of } \\
\text { management measures } \\
\text { for a lower environmental } \\
\text { impact of bottom trawlers }\end{array}$ & $\begin{array}{l}\text { Public research } \\
\text { establishment }\end{array}$ & 11 \\
\hline $\begin{array}{l}\text { Quarterly national } \\
\text { commission on benthic } \\
\text { and demersal fisheries of } \\
\text { the Bay of Biscay }\end{array}$ & Meeting 2 & $\begin{array}{l}\text { Find a common strategy } \\
\text { on the development and } \\
\text { management of seiners in } \\
\text { the Bay of Biscay }\end{array}$ & $\begin{array}{l}\text { National fisheries } \\
\text { committee }\end{array}$ & 15 \\
\hline $\begin{array}{l}\text { "Management plan" } \\
\text { workshop mid-term } \\
\text { meeting, experimental } \\
\text { project of the Grande } \\
\text { Vasière" concerted } \\
\text { exploitation and } \\
\text { management unit }\end{array}$ & Meeting 3 & $\begin{array}{l}\text { Define management } \\
\text { objectives of } \\
\text { management about } \\
\text { Grande Vasière fisheries }\end{array}$ & $\begin{array}{l}\text { Public research } \\
\text { establishment }\end{array}$ & \\
\hline
\end{tabular}

Ordinarily, marine fisheries actors are differentiated by whether they come directly from the fishing industry, government, research, or civil society [86]. As such, each participant represents a socio-professional group and an institution (e.g. government department, NGO, 
trade union) that permits them to attend the meetings. This is why Fig. 5 shows participant distribution by socio-professional group, by individual, and by institution.
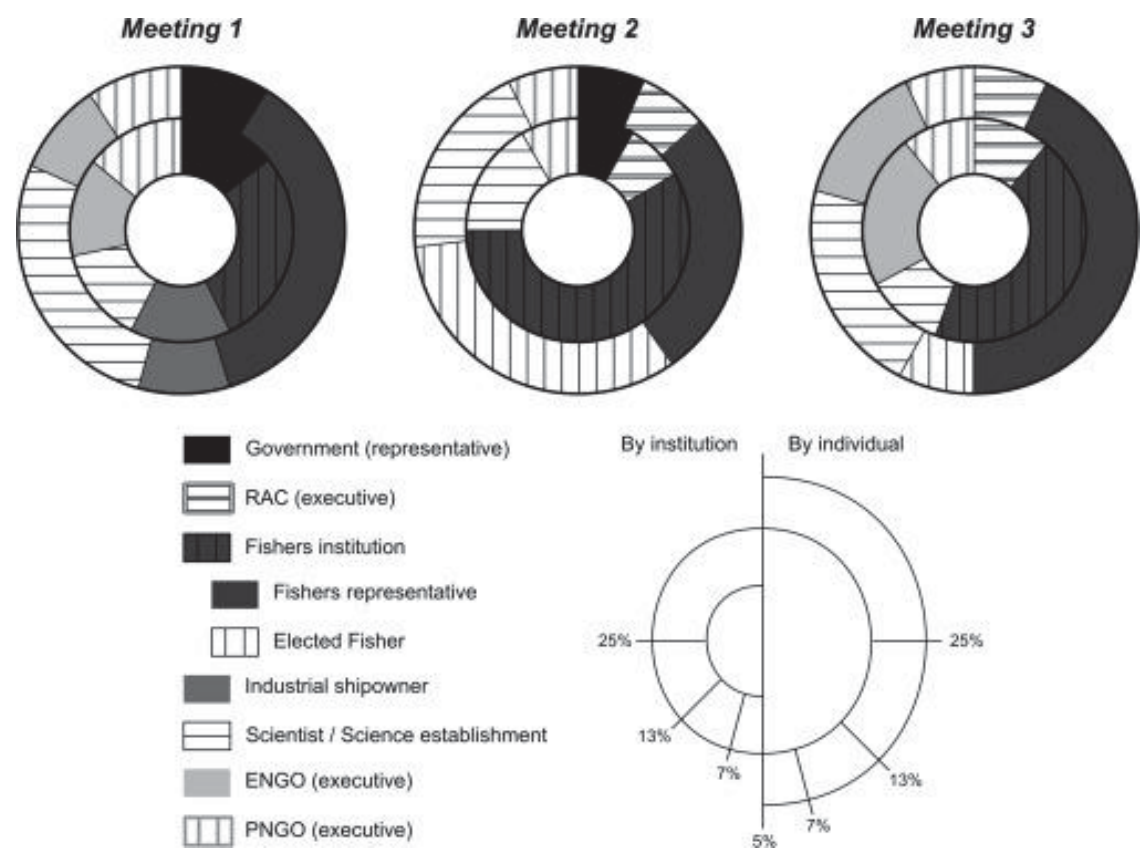

Fig. 5: Participation during the meetings

Fishers are always the dominant group. They are not exactly a homogenous group because some participants are actually elected fishers but others participants are employees of the POs and the fisheries committees. Moreover, elected fishers are mandated from an area or from a métier. The downstream sectors (wholesale fish merchants for example) are never represented and it is rare to find industrial fishing companies who are factory ship owners (only represented at one meeting). National or international, generalist or specialist Environmental NGOs (ENGOs) participate to all meetings and could be considered as the "fish" representatives". The Political NGO (PNGO) attends each meeting too as a representative to the civil society. It is in fact a federation of local authorities as a tool for elected representatives of the area to influence fisheries policy. Finally, the scientists at the meetings are from the private sector or academia. Government representatives were only absent from meeting 3, although this was a co-management experiment between the government and industry professionals.

- Processing actors' discourse

The interactions are therefore considered as sources of social capital and indicators of the actors' ability to get along. Within structures that are, in theory, homogenous, the actors are "multi-dimensional" agents, i.e., they have private (values, representations) and public (status, function) characteristics that are both relatively static (skills, means) and evolving (strategy, capacity building) and that will determine their behaviour in the meeting $[87,88]$. This is why the analysis focuses on interactions between the groups and also between all the actors.

To this end, during the meeting, each discourse, speaker and addressee(s) were noted. At the end of the meeting, speeches were classified into four discourse categories: (i) factual question or a request for information (Question/Request), (ii) answer to this request or additional information (Answer/Information), (iii) proposition or adhesion discourse (Proposition/Adhesion) and (iv) reject or conflictual discourse (Reject/Conflict). 
Consequently, the actors who did not participate orally in the meetings were left out of the following analysis. These criteria were largely inspired by the Systematic Multiple Level Observation of Groups (SYMOG) system and in particular by the "groups with unresolved issues" observation grid by Bales, which was created to analyse experimental meetings using a typology of interactions between actors (organisation or solution/construction or deconstruction) [89, 90]. Table 3 illustrates this treatment from an extract of meeting 3.

Table 3: Examples of the first treatment extract from Meeting 3

\begin{tabular}{|c|c|c|c|c|c|c|}
\hline Example & Speaker & Adressee & $\begin{array}{l}\text { Question or } \\
\text { Request }\end{array}$ & $\begin{array}{l}\text { Answer or } \\
\text { Information }\end{array}$ & $\begin{array}{l}\text { Proposition or } \\
\text { Adhesion }\end{array}$ & $\begin{array}{l}\text { Reject or } \\
\text { Conflict }\end{array}$ \\
\hline $\begin{array}{l}\text { "Our charges are increasing. } \\
\text { The fish price is growing too } \\
\text { but not indefinitely" }\end{array}$ & $\begin{array}{l}\text { Elected } \\
\text { fisherman }\end{array}$ & ENGO 1 & - & $\mathrm{X}$ & - & - \\
\hline $\begin{array}{l}\text { "But there will be a new } \\
\text { regulatory constraint so what do } \\
\text { you propose which destroyed } \\
\text { the less boats as possible?" }\end{array}$ & ENGO 1 & $\begin{array}{l}\text { Elected } \\
\text { fisherman }\end{array}$ & $\mathrm{X}$ & - & - & - \\
\hline $\begin{array}{l}\text { "Biomass grows, fish mortality } \\
\text { lowers and then we have to } \\
\text { reduce the fleet by } 40 \text { per cent. } \\
\text { Do you realize?" }\end{array}$ & $\begin{array}{l}\text { Fishermen } \\
\text { representative }\end{array}$ & ENGO 1 & - & - & - & $\mathrm{X}$ \\
\hline $\begin{array}{l}\text { "Sure, we don't want to broke } \\
40 \text { per cent of the fleet." }\end{array}$ & ENGO 2 & $\begin{array}{l}\text { Fishermen } \\
\text { representative }\end{array}$ & - & - & $\mathrm{X}$ & - \\
\hline $\begin{array}{l}\text { "And finally, it's not just } 40 \text { per } \\
\text { cent. All the fleet would be } \\
\text { damage." }\end{array}$ & $\begin{array}{l}\text { Elected } \\
\text { fisherman }\end{array}$ & ENGO 2 & - & $\mathrm{X}$ & - & - \\
\hline
\end{tabular}

Fig. 6(a) shows that meeting 1 was typified by a set of questions and responses (57\% of the discourse). During meeting 2, where interactions are more reduced, it seems that there was more of a consensus in the exchanges (42\% adhesion compared to $29 \%$ deconstruction of propositions) as opposed to meeting 3 that was more a source of conflict (35\% of the discourse). Fig. 6(b) shows that, all meetings combined, the most active actors were the professional representatives and the scientists, followed by the ENGOs and fishers (83\% of the discourse). South AC, the industrial ship owner, government representatives and the PNGO took a back seat. The chart also shows that the ENGOs and South AC had a tendency to ask questions, and it is mainly the professionals, their representatives, and the scientists who responded. Adhesion and opposition discourses were fairly balanced per actor. There was, therefore, no standard position from a stakeholder to another.
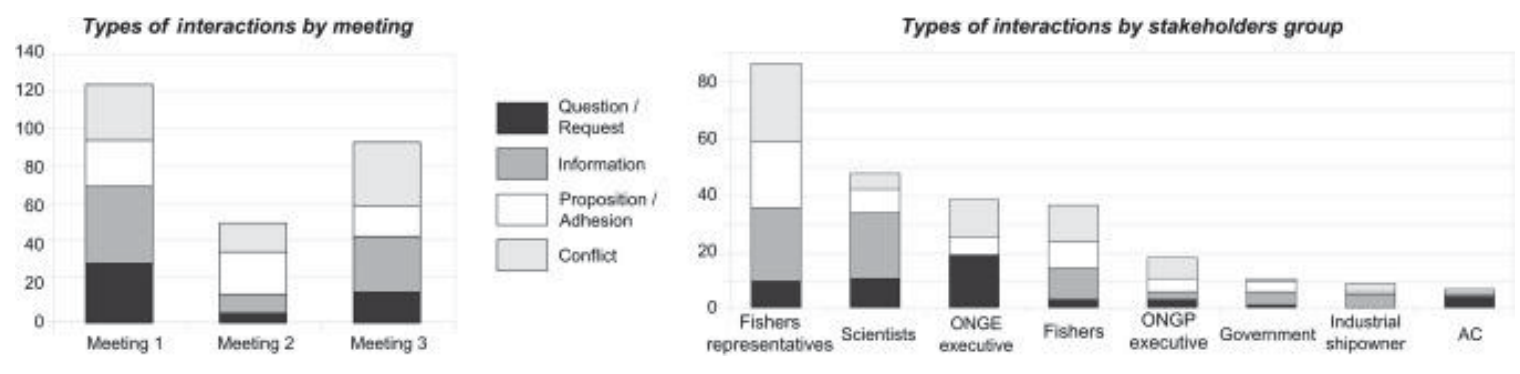

Fig. 6: Interactions during the meetings (1)

- Processing of interactions 
Once the speaker and their addressees were identified, the next step was to interpret the relationship patterns by actor and by group. The Table 4 illustrates this operation with the example of a matrix counting information interactions between stakeholders groups. The matrix shows that during the meeting 1 , actors who were playing more the game of the informer are scientists (with 16 occurrences) and fishers representatives (with 14 occurrences). The both groups were informing each other because scientists' information was addressed to fishers representatives (with 6 occurrences) and fishers representatives' information was addressed to scientists (with 4 occurrences) - and to all participants (with 7 occurrences).

Table 4: Illustration of the second treatment with the example of Information interactions of the meeting 1

\begin{tabular}{|c|c|c|c|c|c|c|c|c|}
\hline \multirow[b]{2}{*}{ Speaker } & \multicolumn{8}{|c|}{ Adressee } \\
\hline & 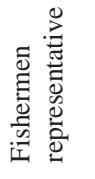 & 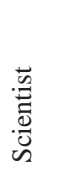 & 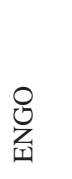 & 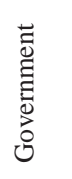 & 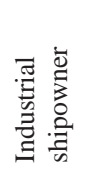 & $\begin{array}{l}0 \\
\text { 足 } \\
\text { Z }\end{array}$ & $\bar{\psi}$ & 点 \\
\hline Fishermen representative & 3 & 4 & 0 & 0 & 0 & 0 & 7 & 14 \\
\hline Scientist & 6 & 1 & 3 & 0 & 2 & 2 & 2 & 16 \\
\hline ENGO & 0 & 0 & 0 & 0 & 0 & 0 & 0 & 0 \\
\hline Government & 2 & 3 & 0 & 0 & 0 & 0 & 0 & 5 \\
\hline Industrial shipowner & 2 & 1 & 0 & 0 & 0 & 0 & 2 & 5 \\
\hline PNGO & 0 & 0 & 0 & 0 & 0 & 0 & 0 & 0 \\
\hline Total & 13 & 9 & 3 & 0 & 2 & 2 & 11 & 40 \\
\hline
\end{tabular}

More generally, the data used to create Table 4 show that during meeting 1 , the scientists and the employee of an ENGO asked the most questions; the former mainly directed questions to the professional representatives and the latter to the scientists. In meeting 2, there was significant conflict between the professionals, which weighted the aforementioned consenting pattern. This conflict between fishers was mitigated by the intervention of their representatives. Finally, for meeting 3, one of the two ENGO employees clashed with most of the other participants, in particular the professional representatives, scientists and the other ENGO.

- Knowledge, convergences and obstructions

To understand the object of conflicts previously introduced, the next step was to identify the themes of the actors' questions/knowledge sharing, common ground and areas of disagreement by examining the content of the actors' discourse. Although the meetings differed, for example in their organisation, the themes addressed were relatively similar from one meeting to the next. As such, in the third section of this paper, these major themes have been translated into key words common to all meetings. Firstly, fishery issues are addressed by domain or field: ecological (Environment), economic (Exploitation), political (Management) or practices (Métier). Then, each field is explored from different angles (Variable) such as how it operates (Functioning), effects and impacts that are felt or induced 
(Impacts), changes that take place (Changes) and cultural representations it elicits (Representation). Finally, the actors participate upstream (Diagnostic) or downstream (Objective) in a potential strategic agreement (Strategy) which can be qualified as "Phase" of the agreement. Several of these key words were allocated to each discourse. One example of this stage is shown in Table 5 which brings to light that the field of the discussion during the meeting 2 was the métier and the exploitation. The angles is mainly the changes: métier conversion, changes in exploitation modalities. Meeting participants are in preliminary discussions because they make the diagnostic about opportunities and limits to converting some bottom trawlers in Danish seine boats

Table 5: Examples of the third treatment extract from the meeting 2

\begin{tabular}{|l|l|l|l|l|l|l|}
\hline \multicolumn{2}{|c|}{ Examples } & & & & \\
\hline
\end{tabular}

From this new processing approach and Fig. 7, it transpires that during meeting 1, the data acquired/to be acquired were essentially based on the functioning of the environment and the impacts of bottom trawling to establish a diagnostic of the Grande Vasière. The aforementioned conflict in meeting 3 was essentially based on the fisheries management strategy in the Grande Vasière (flexible versus radical measures).

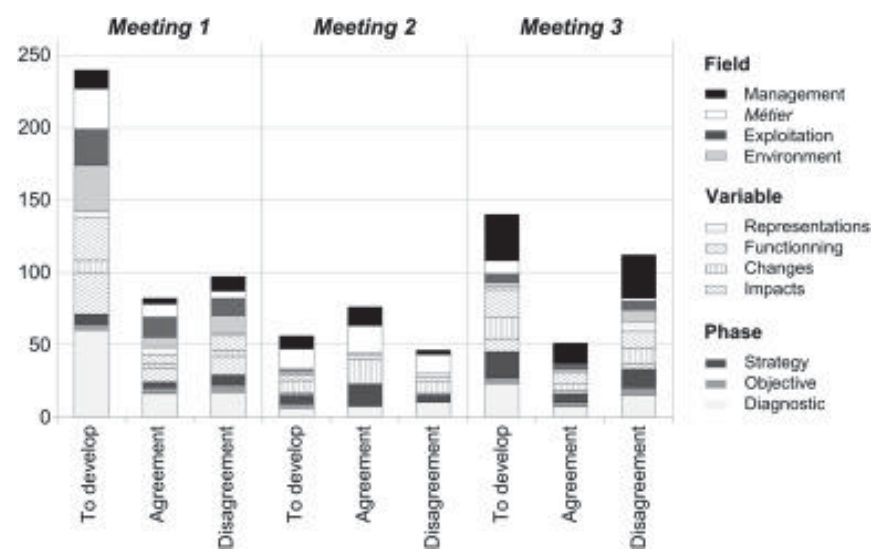


Fig. 7: Interactions during the meetings (2)

- Shaping data with sociograms

Sociograms make it possible to shape the data collected on the relationships between actors and groups of actors to ultimately identify the capacity of in-meeting interactions to provide management methods. Each participant is placed on a chart. Their position on the ordinate axis depends on their discourse. The abscissa axis refers to the themes discussed in the meeting. To provide a visual interpretation of the chart, the actors are put into groups. The main interactions between actors represented by arrows are considered to be alliances (Union), oppositions (Opposition) or "neutral" interactions (Neutral).

Fig. 8 is not the sociogram of the social networks of the fisheries of the Bay of Biscay but it represents actors sub-systems created during observed meetings. The sociogram of the meeting 1 shows three actors group. Two of them are particularly contrasted: the first one is composed by an ensemble of the ENGO and scientists whereas in the second one, the PNGO were closer to the professional representatives. These two groups present an antagonistic position on the impact of bottom trawling. The meeting 1 is also composed by a median group. In the meeting 3, while the scientists and the professional representatives gathered together, the ENGOs were quite marginalised. Confirming the previous analysis, the meeting 2 sociogram shows a split of fishers into different groups of interest in view of métier (i.e. trawlers favourable toward conversion, trawlers not favourable toward conversion, other métiers competitors with trawlers and seiners).

Seen together, meetings sociograms show that fisheries actors system is dynamic beyond the composition of the meetings and independently of the professional profile of stakeholders to which they belong. Sociograms provide then an alternative interpretation of relationships between actors, based on elements on which the they are able to agree and those that are still subject to debate or uncertainty. 

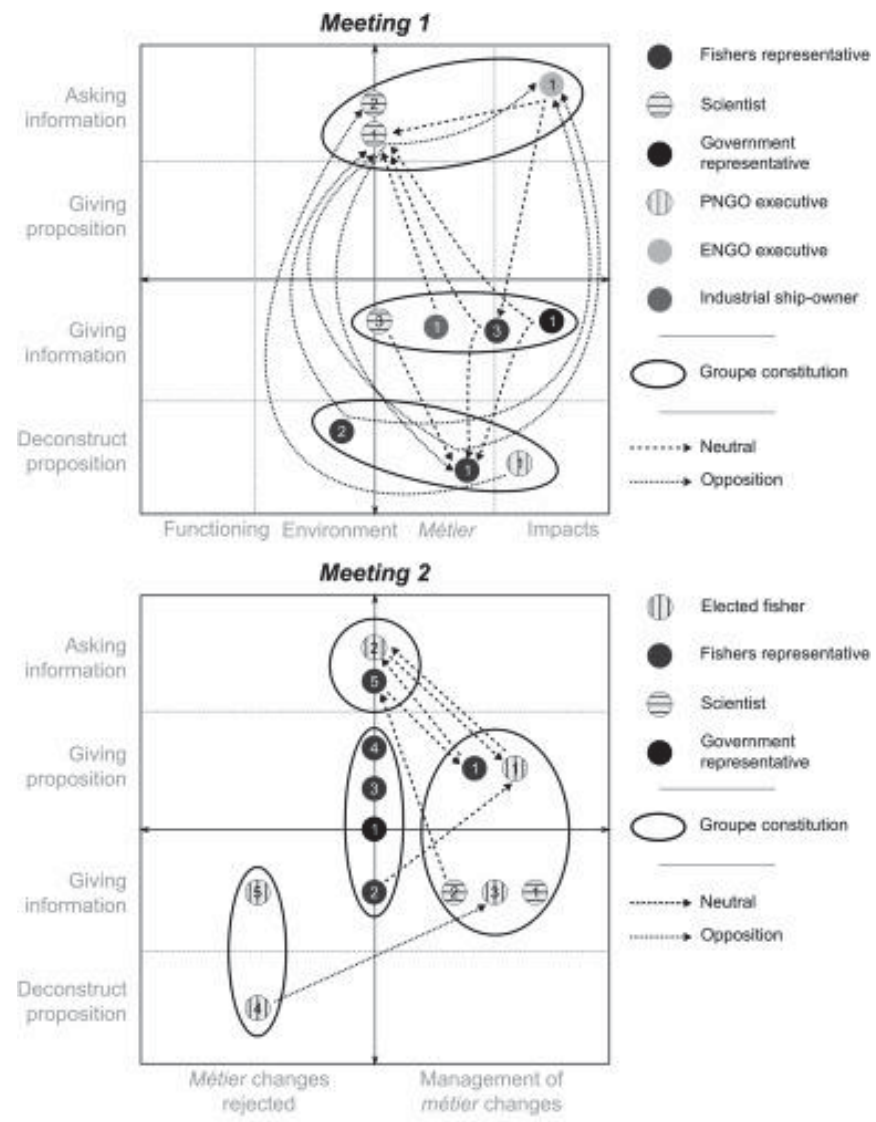

(I) Elected fisher

- Fishers represemative

으 Scientist

Covomment representative
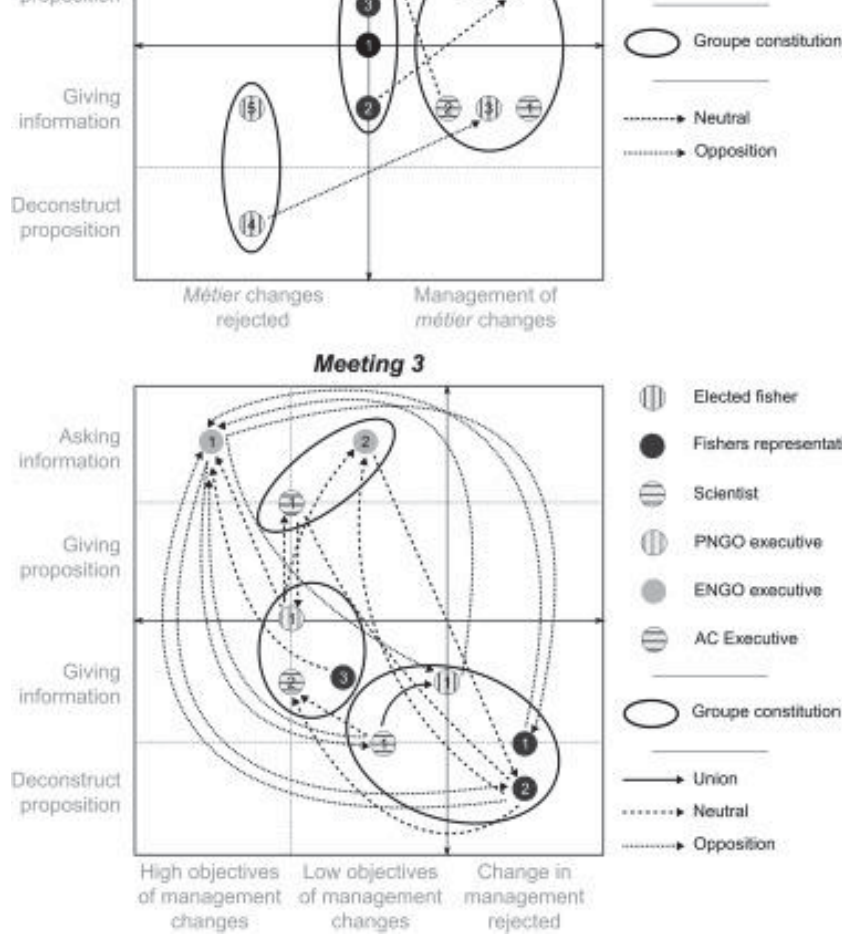

(11) Elected fisher

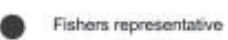

$\Theta$ scientist

(1D) PNGO executive

(1) ENGO executive

F AC Executive

Groupe constitution

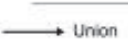

….... Neutral

Fig. 8: Sociograms of the meetings

\section{Discussion}

This exploratory study has highlighted several dialogue certainties that go beyond the meeting framework. However, the chosen method does require self-criticism. Finally, despite the fact that in the CFP there is progressive and partial recognition of governance, the organisation of actors in a network, and efforts to get along, the impact of dialogue on decision-making remains limited.

\subsection{Contributions and limitations of the study}

First, the study has provided valuable information on actor interactions. It observed circumstantial alliances between actors with objectives that seemed paradoxical at first sight 
and internal conflict in groups that supposedly shared similar demands [91]. This observation therefore meant that the study could go beyond certain precursors, for example, the unit of fishers, the historic and systematic conflict that pits them against the ENGOs or the consideration of scientists as objective agents [92, 93].

Next, taking a step back from the observations makes it possible to understand the logical order of the meetings. In fact, it seems that each meeting was an ad-hoc snapshot of the same continuum. Meeting 1 , at the beginning of the collaborative scientific project, was useful for an exchange of information, a co-production of expert and lay knowledge between actors. With many collective reference points, the actors are then able to concur on the terms of their agreement. Meeting 3 showed this transition between the construction of social capital and collective action. Although meeting 2 was a routine meeting, it is a perfect example of the ultimate goal of dialogue, namely the construction of a common vision in a system of "interknowledge and inter-recognition" [76].

Finally, the different meetings had common objects. The fishery in the Grande Vasière was present in meeting 1 and meeting 3, and some of the same actors participated in both meetings - although it is interesting to note that their position, their discourse and their relations changed. This confirms Beuret's theory on "dialogue processes" [94], that is, the long-term path of a discussion between actors that takes place on "stages" and "arenas" that are both foreseen and improvised, formal and informal, to finally give coherence to governance. Similarly, meeting 1 and meeting 3 belong to the same process.

The study also has its weaknesses. The analysis was based on the observation of three daylong meetings. The sample was therefore extremely limited. It would have been interesting to complement this work with observations of other meetings or with the follow up of these three dialogue projects, as highlighted and proposed by other authors [28, $73,74,95]$. In other respects, this study aimed to be an objective analysis of social facts, under the guise of quantification. In fact, the research would have been stronger had it been enriched by more qualitative methods to better characterise the social challenges at play in meetings and the actors' behaviour [96], and by an improved integration of the findings in the three meetings. A further criticism of this study is that actors were not given any feedback. Their participation in the construction of sociograms would have provided a more in-depth understanding of actor interaction and would have legitimised a study with a strong bias towards stakeholder investment. A such "collaborative observation" step [96] could have completed the study but after the non-participative observation steps to avoid bias on participants behavior during meetings.

\subsection{Dialogue: its pitfalls and contribution to governance}

Some months after the field observations, the professionals agreed on a management strategy for some benthic and demersal stocks in the Bay of Biscay (e.g. multi-annual quotas of Common sole, selectivity measures for Norway lobster). Scientists considered this scenario to be good for achieving the Maximum Sustainable Yield (MSY) and the ENGOs agreed. The ACs sent it to European decision-makers, but the scenario was not chosen for inclusion in the European legislation establishing fishery options.

Although each meeting observed was considered to be part of a dialogue, this failure must be understood in the difference between dialogue in the strict sense of the term, consultation and negotiation and in their impacts on decision-making. More powerful than consultation in participation terms, concertation alone cannot guarantee a policy decision consistent with the actors' discussions, but only an understanding, as opposed to negotiation [94]. According to 
this definition, it is not surprising that arbitration differs with the will of the actors. Nevertheless, the main criteria of decision-making are, in the case of fisheries policy, already defined outside of the projects (MSY, Good Environmental Status (GES), ban on discards) whereas dialogue must be an endogenous initiative (which is the case here) enabling actors to construct their own objectives and means of action (which is not the case here) [73, 94, 97].

\section{Conclusion}

Hardin's neoclassical approach is called into question and for at least three decades, governance in general and environmental governance in particular have been met with equal enthusiasm from social science researchers and non-governmental institutions. In fisheries, the state of the art shows that the majority of applications are limited to artisanal subsistence fisheries. It would appear that Ostrom's governance analysis tools cannot be easily applied to contemporary European fisheries where regionalisation and stakeholder involvement are insufficient. Nevertheless, a documentary research has revealed that the European Union and France had created tools to delegate some fisheries competences to stakeholder: PO, AC, fisheries committees. Besides, actors multiplied multi-partner process to organised themselves of which observed meetings are just a sample. So, the CFP recognise the governance as a management way.

The field study was based on the fact that thanks to social interactions occurring during these cooperation scenes - or these governance levers - actors build social capital to propose management measures. No meeting directly led to management plan but with time stakeholders have make a management measures proposition to European Union. Both hypotheses on (i) the lack of structure of the stakeholder network and (ii) it inability to have an agreement are then rejected. The explanation of the opposition of the European Union to adopt the proposition of the actors of the Bay of Biscay is elsewhere. The meetings observed appeared to be based on incomplete concertation and lacked credibility with decision-makers in a context where governance and the systematic involvement of fishery stakeholders is a culture that is currently under construction $[98,99]$.

\section{References}

[1] Hardin G. The tragedy of the commons. The population problem has no technical solution, it requires a fundamental extension in mortality. Science 1968;162:1243-8.

[2] Devictor V. Nature en crise: Penser la biodiversité. Paris: Editions du Seuil; 2015.

[3] Gordon HS. The economic theory of a common-property resource: the fishery. The Journal of Political Economy 1954;62:124-42.

[4] Hannesson R. The privatization of the oceans. Cambridge: The MIT Press; 2004.

[5] Clark CW. Fisheries bioeconomics: why is it so widely misunderstood? Population Ecology 2006;48:95-8.

[6] McWhinnie SF. The tragedy of the commons in international fisheries: An empirical examination. Journal of Environmental Economics and Management 2009;57:321-33.

[7] Abbott JK, Wilen JE. Dissecting the tragedy: A spatial model of behavior in the commons. Journal of Environmental Economics and Management 2011;62:386-401.

[8] Kraak SBM. Exploring the "public goods game" model to overcome the Tragedy of the Commons in fisheries management. Fish and Fisheries 2011;12:18-33. 
[9] Feeny D, Berkes F, McCay BJ, Acheson JM. The tragedy of the commons: Twenty-two years later. Human Ecology 1990;18:1-19.

[10] Locher F. Les paturages de la Guerre Froide: Garett Hardin et la "tragédie des communs." Revue D’histoire Moderne et Contemporaine 2013;60:7-36.

[11] Boncœur J, Guyader O, Thébaud O. A typology of fisheries management tools. Brest: AMURE Publications; 2006.

[12] Ostrom E. Public entrepreneurship: a case study in ground water basin management. Political science. UCLA, 1964.

[13] Ostrom E. Governing the Commons: The Evolution of Institutions for Collective Action. Cambridge: Cambridge University Press; 1990.

[14] Dietz T, Ostrom E, Stern PC. The Struggle to Govern the Commons. Science 2003;302:1907-12.

[15] Jentoft S. Organisasjon og ansvar: lokale koordineringsproblemer i fiskerinæringen. Oslo: Universitetsforlaget; 1981.

[16] Berkes F. Local-level management and the commons problem: A comparative study of Turkish coastal fisheries. Marine Policy 1986;10:215-29.

[17] Pomeroy RS, Berkes F. Two to tango: The role of government in fisheries comanagement. Marine Policy 1997;21:465-80.

[18] Gray T. Participation in fisheries governance. Dordrecht: Springer; 2005.

[19] Kooiman J, Bavinck M, Jentoft S, Pullin R. Fish for life interactive governance for fisheries. Amsterdam: Amsterdam University Press; 2005.

[20] McCay BJ. The littoral and the liminal: Challenges to the Management of the Coastal and Marine Commons. Maritime Anthropological Studies 2008;7:7-30.

[21] Sugden A, Ash C, Hanson B, Smith J. Where do we go from here? Science 2003;302:1906.

[22] Hufty M. Jeux de gouvernance. Regards et réflexions sur un concept. Genève: IUED; 2007.

[23] Calame P, Freyss J, Garandeau V. La démocratie en miettes: Pour une révolution de la gouvernance. Paris: Descartes \& Cie; 2003.

[24] Jessop B. State Power. Second Edition. Cambridge: John Wiley \& Sons; 2013.

[25] Baron C. La gouvernance: débat autour d'un concept polysémique. Droit et Société 2003;54:329-51.

[26] Lévy J, Lussault M. Dictionnaire de la géographie. Belin. Paris: 2003.

[27] Symes D. Fisheries governance: A coming of age for fisheries social science? Fisheries Research 2006;81:113-7.

[28] Agrawal A, Gibson C. Enchantment and disenchantment: The role of community in natural resource conservation. World Development 1999;27:629-49.

[29] Symes D. Fisheries management: in search of good governance. Fisheries Research 1997;32:107 - I 14. 
[30] Mahévas S, Pelletier D. ISIS-Fish, a generic and spatially explicit simulation tool for evaluating the impact of management measures on fishery dynamics. Ecological Modelling 2004;171:65-84.

[31] Wilson DCK. European mixed fisheries as a complex commons. Natures Sciences Sociétés 2012;20:66-74.

[32] Rey, H., J. Catanzano, B. Mesnil et G. Biais, Système halieutique. Un regard différent sur les pêches, Paris: Institut océanographique-IFREMER, 1997

[33] Laloë F. Quelle(s) complexité(s) pour quelle(s) décision(s). Halieutique: Complexité et décision, Lorient: Ifremer; 2001, p. 25.

[34] Ostrom E. A general framework for analyzing sustainability of social-ecological systems. Science 2009;325:419-22.

[35] Corlay J-P. La notion d'espace de production halieutique: proposition méthodologique d'étude à partir de l'exemple danois. Norois 1979;104:449-66.

[36] Kooiman J. Governing as Governance. London: SAGE; 2003.

[37] Jentoft S. Limits of governability: institutional implications for fisheries and coastal governance. Marine Policy 2007;31:360-70.

[38] Jentoft S, Chuenpagdee R. Fisheries and coastal governance as a wicked problem. Marine Policy 2009;33:553-60.

[39] Jentoft S, Chuenpagdee R, Bundy A, Mahon R. Pyramids and roses: alternative images for the governance of fisheries systems. Marine Policy 2010;34:1315-21.

[40] Ortolland D, Pirat J-P. Atlas géopolitique des espaces maritimes. Frontières, énergie, transport, piraterie, pêche et environnement. Paris: Technip; 2010.

[41] Données de ventes déclarées en halles à marée 2013. Paris: FranceAgriMer; 2014.

[42] Deporte N, Ulrich C., Mahévas S, Demanèche S, Batardie F. Regional metier definition: a comparative investigation of statistical methods using a workflow applied to international otter trawl fisheries in the North Sea. ICES Journal of Marine Science 2012;69:331-342.

[43] Fontaine B, Warluzel N. Biologie de la langoustine du golfe de Gascogne Nephrops norvegicus. Revue Des Travaux de l'Institut Des Pêches Maritimes 1969;33:223-46.

[44] Macher C. Productions jointes et mesures de gestion des pêcheries mixtes: application à la pêcherie langoustinière du golfe de Gascogne. Sciences Economiques. Université de Bretagne Occidentale, 2008.

[45] Belloc G. Poissons de chalut. Etude monographique du merlu Merluccius merluccius (Troisième partie). Revue Des Travaux de l'Office Scientique et Technique Des Pêches Maritimes 1935;30:145-202.

[46] Kacher M. Le merlu du golfe de Gascogne et de la mer celtique. Croissance, répartition spatiale et bathymétrique, écologie alimentaire et assemblaes. Université du Littoral - Côte d'Opale, 2004.

[47] Drouineau H. Développement et ajustement d'un modèle de dynamique des populations structuré en longueur et spatialisé appliqué au stock Nord de merlu (Merluccius merluccius). Hlieutique. AgroCampus, 2008. 
[48] Arbault S, Camus P, Le Bec S. Estimation du stock de sole dans le golfe de Gascogne à partir de la production d'oeufs. Journal of Applied Ichtyology 1986;2.

[49] Le Pape O, Guerault D, Désaunay Y. Effect of an invasive mollusc, American slipper limpet Crepidula fornicata, on habitat suitability for juvenile common sole Solea solea in the Bay of Biscay. Marine Ecology Progress Series 2004;277.

[50] Mardle S, Pascoe S, Boncoeur J, Le Gallic B, Garcia-Hoyo JJ, Herrero I, Jimenez-Toribo R, Cortes C, Padilla N, Raakjer Nielsen J, Mathiesen C. Objectives of fisheries management : case studies from the UK, France, Spain and Denmark. Marine Policy 2002;26415-428.

[51] Book 7 Bay of Biscay and Atlantic Iberian Waters. Copenhaguen: ICES; 2013.

[52] Girardon J. Politiques d'aménagement du territoire. Paris: Ellipses; 2006.

[53] Perraudeau Y. Chapitre 1. Les politiques des pêches et de l'aquaculture en France et en Europe. Mare economicum. Enjeux et avenir de la France maritime et littorale, Rennes: Presses Universitaires de Rennes; 2008, p. 25-67.

[54] Cochrane K, Garcia S. A fishery manager's guidebook. Second Edition. Oxford / Rome: Wiley-Blackwell / FAO; 2009.

[55] Symes D. Fisheries management and institutional reform: a European perspective. ICES Journal of Marine Science 2007;64:779-85.

[56] Symes D, Phillipson J. Whatever became of social objectives in fisheries policy? Fisheries Research 2009;95:1-5.

[57] Khalilian S, Froese R, Proelss A, Requate T. Designed for failure: A critique of the Common Fisheries Policy of the European Union. Marine Policy 2010;34:1178-82.

[58] Urquhart J, Acott T, Reed M, Courtney P. Setting an agenda for social science research in fisheries policy in Northern Europe. Fisheries Research 2011;108:240-7.

[59] Gascuel D, Bez N, Forest A, Guillotreau P, Laloë F, Lobry J, et al. A future for marine fisheries in Europe (Manifesto of the Association Française d'Halieumétrie). Fisheries Research 2011;109:1-6.

[60] Froese R. Generic harvest control rules for European fisheries. Fish and Fisheries 2011;12:340-51.

[61] Salomon M, Markus T, Dross M. Masterstroke or paper tiger - the reform of the EU's CFP. Marine Policy 2014;47.

[62] Le Bihan D. Organisations de producteurs des pêches maritimes en France et droit communautaire. Brest: Centre National pour l'Exploitation des Océans; 1977.

[63] D’Artigues M, Catanzano J, Lebon Le Squer D, Rey H. Les organisations de producteurs des pêches maritimes françaises. Situation et typologie. Ifremer; 1995.

[64] Lebon Le Squer D. Les organisations de producteurs des pêches maritimes françaises. La recherche d'une échelle pertinente d'intervention. Géographie. Université de Nantes, 1998.

[65] Le Fur F. Pêche professionnelle. Activités - Interactions - Dispositifs d'encadrement. Agence des Aires Marines Protégées; 2009.

[66] Aanesen M, Armstrong C, Van Hoof L. The changing environment of fisheries policy in Europe. Marine Policy 2012;36:1172-7. 
[67] Lelong S. La gouvernance des pêches communautaires à l'interface entre ressources et société. Perspectives juridiques, biologiques et socioéconomiques. Droit. Université de Nantes, 2012.

[68] Ounanian K, Hegland T. The Regional Advisory Council's current capacities and unforseen benefits. Maritime Studies 2012;11.

[69] Hatchard J, Gray T. From RACs to Advisory councils: lessons from North Sea discourse for the 2014 reform of the European CFP. Marine Policy 2014;47:87-93.

[70] Arrêté du 27 septembre 2011 relatif à la composition et au fonctionnement des conseils maritimes de façade.

[71] Jentoft S. Institutions in fisheries: what they are, what they do, and how they change. Marine Policy 2004;28:137-49.

[72] Mikalsen KH, Hernes H-K, Jentoft S. Leaning on user-groups: The role of civil society in fisheries governance. Marine Policy 2007;31:201-9.

[73] Berghöfer A, Wittmer H, Rauschmayer F. Stakeholder participation in ecosystem-based approaches to fisheries management: A synthesis from European research projects. Marine Policy 2008;32:243-53.

[74] Beuret J-E, Cadoret A. Une gouvernance territoriale endogène de l'environnement: contours et enjeux. Géographie, Economie, Société 2011;13:363-86.

[75] Iglesias-Malvido C, Garza-Gil D, Varela-Lafuente M. Management systems in the EU fisheries. Marine Policy 2002;26:403-13.

[76] Goffman E. Interaction ritual, essays in face-to-face behavior. New Brunswick, London: AldlineTransaction, 1967

[77] Blumer H. Symbolic interactionism: perspective and method. Englewood Cliffs: Prentice Hall, 1969

[78] Bourdieu P. Le capital social. Notes provisoires. Actes de La Recherche En Sciences Sociales 1980;31:2-3.

[79] Coleman JS. Social capital in the creation of human capital. American Journal of Sociology 1988;94:95-120.

[80] Kopelman NR, Weber JM, Messick DM, Committee on the Human Dimensions of Global Change, National Research Council. Factors influencing cooperation in commons dilemmas: A review of experimental psychological research. The Drama of the Commons, Washington: National Academies Press; 2002, p. 113-56.

[81] Pretty J. Social capital and the collective management of resources. Science 2003;302:1912-4.

[82] Grafton RQ. Social capital and fisheries governance. Ocean \& Coastal Management 2005;48:753-66.

[83] Garett A, MacMullen P, Symes D. Fisheries as learning systems: Interactive learning as the basis for improved decision making. Fisheries Research 2012;127-128:182-7.

[84] Trimble Nuñez M. Towards adaptive co-management of artisanal fisheries in coastal Uruguay: analysis of barriers and opportunities with comparisons to Paraty (Brazil). Philosophy. University of Manitoba, 2013. 
[85] Mermet L. La "concertation": un terme flottant pour un domaine mouvant? Négociations 2006;5:75.

[86] Mackinson S, Wilson DC, Galiay P, Deas BC. Engaging stakeholders in fisheries and marine research. Marine Policy 2011;35:18-24.

[87] Crozier M, Friedberg E. L'acteur et le système. Les contraintes de l'action collective. Paris: Editions du Seuil; 1977.

[88] Pennanguer S. Incertitude et concertation dans la gestion des zones côtières. Halieutique. ENSAR, 2005.

[89] Bales RF. Rôles centrés sur la tâche et rôles sociaux dans les groupes ayant des problèmes à résoudre. Psychologie sociale. Textes fondamentaux anglais et américains. Tome 1, Paris: Dunod; 1972, p. 263-77.

[90] Bales RF. Social Interaction Systems: Theory and Measurement. New Brunswick, New Jersey: Transaction Publishers; 2002.

[91] Lazuech G. Comment gérer les ressources marines? Les jeux d'acteurs autour de la Politique commune des pêches. Économie Rurale Agricultures, Alimentations, Territoires 2014:29-44.

[92] Callon M. Eléments pour une sociologie de la traduction. La domestication des coquilles Saint-Jacques et des marins-pêcheurs dans la baie de Saint-Brieuc. L'Année Sociologique 1986;36:37-44.

[93] Morales MC, Harris LM. Using subjectivity and emotion to reconsider participatory natural resource management. World Development 2014;64:703-12.

[94] Beuret J-E, Pennanguer S, Tartarin F. D'une scène à l'autre, la concertation comme itinéraire. Natures Sciences Sociétés 2006;14:30-42.

[95] Ahn TK, Ostrom E, Walker J. Reprint of: A common-pool resource experiment with postgraduate subjects from 41 countries. Ecological Economics 2011;70:1580-9.

[96] Bouillon F, Monnet J. Editorial. L'observation et ses angles : au cœur des rapports entre les chercheurs et leurs objets. Espaces et Sociétés 2016;164-165:9-17.

[97] Touzard H. Consultation, concertation, négociation: Une courte note théorique. Négociations 2006;5:67.

[98] Hatchard J, Gray T. Stakeholders and the reform of the European Union's Common Fisheries Policy: The institutionalisation of a consultation culture. Maritime Studies (MAST) 2003;2:5-20.

[99] Mikalsen KH, Jentoft S. Participatory practices in fisheries across Europe: Making stakeholders more responsible. Marine Policy 2008;32:169-77. 